\title{
PENGEMBANGAN USAHA IKAN NILA DI DESA MERANGIN KECAMATAN KAMPAR RIAU
}

\author{
Syafriani $^{1}$, Dwi Viora ${ }^{2}$, Astuti $^{3}$ \\ ${ }^{1}$ Fakultas Ilmu Kesehatan, Universitas Pahlawan Tuanku Tambusai \\ ${ }^{2,3}$ Fakultas Ilmu Pendidikan, Universitas Pahlawan Tuanku Tambusai \\ Email: syafrianifani@ymail.com
}

\begin{abstract}
Tilapia farmers in Kampar Regency independently cultivate tilapia. Partners experience very minimal capital constraints, where the price of seeds and feed is increasing, while the selling price of tilapia is likely to be constant or even decline. The purpose of this activity is to help tilapia farmers to increase revenue and selling value of tilapia produced by the provision of pellet machines. The obstacle faced by partners is the high price of feed causing high prices of production, while the selling power of tilapia is low. This is what causes the small profits obtained by tilapia farmers. Activities undertaken in the PKM program are the use of IPTEKS in terms of tilapia production by providing feed / pellet machines, this effort aims to reduce dependence on commercial feed sold at relatively high prices. This activity was carried out in July by giving pellets to partners. By giving this machine can increase the income of tilapia farmers. The price of commercial pellets is $R p$ 8,620, while the price of feed using the pellet machine is $R p$ 4,000. The difference in profits obtained by indigo farmers by providing pellets is $R p 4,620$. So that the use of pellet machines can increase the income of tilapia partners.
\end{abstract}

Keywords: tilapia, pellet machine, marketing, income

\begin{abstract}
Abstrak. Petani ikan nila di Kabupaten Kampar melakukan budidaya ikan nila secara mandiri. Mitra mengalami kendala dalam modal yang sangat minim, dimana harga benih dan pakan yang semakin meningkat, sedangkan harga jual ikan nila yang cenderung tetap atau bahkan mengalami penurunan. Tujuan kegiatan ini untuk membantu petani ikan nila untuk meningkatkan pendapatan dan nilai jual nila yang dihasilkan dengan pemberian mesin pelet. Kendala yang dihadapi mitra yaitu tingginya harga pakan menyebabkan tingginya harga produksi, sedangkan daya jual ikan nila rendah. Hal inilah yang menyebabkan sedikitnya keuntungan yang diperoleh petani ikan nila. Kegiatan yang dilakukan pada program PKM ini adalah penggunaan IPTEKS dalam segi produksi ikan nila yaitu dengan pemberian mesin pakan/pelet, upaya ini bertujuan untuk mengurangi ketergantungan terhadap pakan komersil yang dijual dengan harga yang relative tinggi. Kegiatan ini dilaksanakan pada bulan Juli dengan pemberian mesin pelet kepada mitra. Dengan pemberian mesin ini bisa meningkatkan pendapatan petani ikan nila. Harga pelet komersil adalah Rp 8.620,-, sedangkan harga pakan dengan penggunaan mesin pelet adalah Rp 4.000,-. Adapun selisih keuntungan yang didapat oleh petani nila dengan pemberian mesin pelet adalah Rp4.620,-. Sehingga penggunaan mesin pelet dapat meningkatkan pendapatan mitra ikan nila.
\end{abstract}

Kata kunci : ikan nila, mesin pellet, pemasaran, pendapatan

\section{PENDAHULUAN}

Kabupaten Kampar dikenal sebagai penghasil ikan nila terbesar di Kabupaten Kampar. Tingginya produksi ikan nila di Kampar menumbuhkan harapan baru, sebagai daerah penghasil terbesar tentunya ikan nila di daerah ini sangat mudah didapatkan dan harganya relatif murah, sehingga dapat menjadi potensi dalam pengembangan kegiatan menjadi produk yang banyak variasinya.

Dilihat dari manfaatnya, ikan nila merupakan jenis makanan sehat yang rendah lemak jenuh, tinggi protein yang baik dikonsumsi oleh segala usia. Ikan nila juga merupakan sumber penting asam lemak omega 3, selenium dan taurin yang berfungsi untuk merangsang pertumbuhan dan perkembangan sel otak terutama bagi balita dan anak anak. Selain itu kandungan vitamin dan mineral yang terdapat pada ikan nila cukup besar bila dibandingkan dengan jenis ikan air tawar lainnya.

Tingginya kandungan protein yang terkandung dalam daging ikan nila $(20,08 \mathrm{~g} / 100 \mathrm{~g})$ dan $50 \mathrm{mg} / 100 \mathrm{~g}$ kolestrol, maka manfaat ikan nila sangatlah bagus bagi yang menjalankan program diet karena bisa mengurangi asupan kolesterol harian di dalam menu makanan (Andriani, 2014). 
Desa Merangin merupakan salah satu desa penghasil ikan nila di Kabupaten Kampar. Usaha ikan nila yang ada di desa Merangin hanya sebatas usaha budidaya saja. Hal ini terkadang menyebabkan petani nila kesulitan dan menjual ikan nila segar. Petani nila menjual nila segar lagsung kepada pengepul yang datang langsung ke kolom ikan dengan harga yang relative murah, sedangkan biaya produksi meliputi bibit dan pakan selalu mengalami kenaikan. Hal ini menjadi penyebab Kabupaten kampar menjadi Produsen ikan terbesar di Riau. (Dinas Perikanan Provinsi Riau, 2015)

Berdasarkan hasil observasi lapangan diperoleh bahwa petani ikan nila di wilayah ini melakukan budidaya ikan nila secara mandiri. Mitra mengalami kendala dalam modal yang sangat minim, dimana harga benih dan pakan yang semakin meningkat, sedangkan harga jual ikan nila yang cenderung tetap atau bahkan mengalami penurunan. Ikan nila yang dihasilkan petani, akan langsung dijual ke pengepul dengan harga Rp. 23.000 per kg. Hasil panen yang melimpah memungkinkan untuk diolah menjadi produk pangan alternative yang sangat digemari masyarakat seperti abon, nugget dan kerupuk ikan yang saat ini keberadaannya di pasaran masih sangat sedikit sehingga usaha makanan berbasis ikan nila memiliki potensi yang luar biasa. Jika usaha ini di kembangkan dengan baik, diharapkan nantinya bisa meningkatkan perekonomian petani ikan nila. keanekaragam produk perikanan sangat diperlukan saat ini untuk menangapi anjuran pemerintah dan juga keinginan masyarakat konsumen yang sudah bepikiran praktis sehingga membutuhkan makanan yang siap saji. (Purnomo \& Suhanda, 2014)

Menurut Dinas Perikanan Kabupaten Kampar ( 2013) kendala yang dihadapi oleh pemilik ikan nila bisa ditanggulangi dengan cara meningkatkan daya saing produk olahan ikan salai nila dengan cara memperbaiki pengemasan dan memperhatikan sanitasi agar bisa bersaing di pasar nasional. Adapun tujuan kegiatan ini adalah Peningkatan pendapatan petani melalui pemberian mesin pelet.

\section{METODE PENELITIAN \\ Peningkatan Kapasitas Ipteks dalam Sistem Produksi}

Petani ikan nila memiliki bebe rapa kelemahan terutama disebabkan karena keterbatasan peralatan produksi yang ada. Tingginya harga pakan dipasaran, membuat biaya produksi yang tinggi, disisi lain harga jual ikan nila rendah. Petani nila menjual ikan nila ke pengepul yang datang ke kolam dengan harga yang rendah, yaitu hanya Rp. 23.000,- per kg. Teknologi proses yang akan diterapkan dalam proses pengolahan ikan salai nila mitra adalah :

\section{Pembuatan Alat Pencetak Pakan Ikan/Pelet}

Selama ini petani nila mengeluhkan harga pelet pabrikan yang samakin meningkat harganya, sedangkan harga jual ikan nila tetap, bahkan bisa mengalami penurunan. Oleh karena itu, untuk mengatasi masalah ini program PKM ini akan memberikan mesin pencetak pakan/ pelet. Pembuatan pellet dapat dilakukan dengan secara manual dan mekanis. Pembuatan pellet secara manual dilakukan dengan cara mencampur bahan - bahan yang sudah dihitung komposisinya, diberi air panas $\pm 80-100{ }^{\circ} \mathrm{C}$ sambil diaduk sampai semua bahan tercampur dengan merata, kemudian digiling dan dicetak menggunakan alat penggiling daging, baru dipotong sesuai dengan ukuran pelet yang diinginkan, setelah itu dikeringkan. Pada proses pembuatan pellet secara manual memerlukan tenaga manusia dalam pembuatannya, serta kapasitas produksi tidak bisa banyak, karena alat yang digunakan untuk menggiling terlalu kecil, akibatnya membutuhkan waktu yang lama untuk menghasilkan pellet dalam jumlah banyak dan hasil pelletnya juga masih kurang padat, sehingga kualitas pellet masih sangat rendah.(Leksono, Setiyo, \& Tika, 2014)

\section{Perubahan Strategi Pemasaran}

Selama ini kekurangan yang dimiliki oleh mitra selain harga pakan yang tinggi dan harga jual yang tinggi, adalah ikan nila hanya dijual ke pengepul dan pada saat ada pasar mingguan. Strategi yang dilakukan dari sisi perluasan pasar dilakukan dengan memperluas daerah penjualan dan lokasi penjualan yang strategis seperti di 
warung-warung milik masyarakat, pasar mingguan di desa lain dan beberapa mini market.

Metode pelaksanaan yang dilakukan agar solusi yang ditawarkan dapat disalurkan dengan baik kepada mitra sesuai yang diharapkan upaya yang dilakukan adalah dengan memberikan penyuluhan dan pelatihan kepada Mitra industri kecil nila.

Tahapan-tahapan pelaksanaan kegiatan pengabdian ini antara lain:

\section{Penyuluhan}

Dalam kegiatan penyuluhan ini, mitra akan dibekali dengan materi penyuluhan tentang cara mengembangkan usaha industri kecil ikan nila dengan melakukan peningkatan kapasitas Iptek dalam sistem produksi, peningkatan produksi olahan ikan nila, serta perubahan strategi pemasaran.

\section{Pelatihan}

Pelatihan yang diberikan adalah dalam bentuk demonstrasi secara langsung mengenai cara pembuatan pelet ikan menggunakan mesin pelet.

\section{Uji Coba}

Uji coba dilakukan untuk melihat capaian hasil kegiatan penyuluhan dan pelatihan. Uji coba pembuatan produk akan dilakukan dalam skala kecil, Tujuan dari pengujian ini adalah agar produk yang dihasilkan memenuhi

\section{Rancangan Monitoring dan Evaluasi}

Monitoring dan evaluasi dilakukan selama berjalannya program. Tujuan dari pelaksanaan monitoring dan evaluasi adalah untuk mengetahui sejauh mana pemahaman mitra terhadap aplikasi ipteks, pengetahuan pengembangan produksi dan pengetahuan tentang sistem pemasaran yang telah diberikan.

\section{Partisipasi Mitra}

Mitra berperan besar dalam kegiata IbM ini. Peran mitra adalah mengikuti penyuluhan, pelatihan, dan ujicoba yang akan diberikan oleh tim pengusul dan ikut serta dalam pengambilan keputusan akhir untuk menerapkan solusi yang ditawarkan. Mitra bertanggungjawab terhadap seluruh pekerja di dalam lingkungan usahanya yang dibantu oleh tim pengusul dan mahasiswa.

\section{HASIL DAN PEMBAHASAN \\ Hasil Pelaksanaan Kegiatan}

Kegiatan pelatihan ini dilaksanakan dalam beberapa tahap yaitu tahap persiapan (penetapan daerah dan penseleksian mitra) dan tahap pembelajaran (penggunaan IPTEKS untuk pembuatan pakan ikan nila berupa pelet dan pelatihan pembuatan makanan olahan dari ikan nila). Kegiatan ini dilaksanakan dari bulan April sampai dengan bulan September 2019, terdiri dari kegiatan penyampaian materi teori dan praktek teknologi pembuatan pelet menggunakan mesin pelet nila

\section{1) Peningkatan Kapasitas Ipteks dalam Sistem Produksi Pembuatan Mesin Pelet}

Tujuan dari pelaksanaan kegiatan ini adalah untuk mengurangi biaya produksi terutama pakan ikan yang harganya semakin mahal serta memanfaatkan ikan nila menjadi produk yang memiliki nilai ekonomis tinggi dan berdaya saing, untuk meningkatkan pendapatan keluarga sebagai usaha mata pencaharian masyarakat, dan mengembangkan produk menjadi produk unggulan yang berbasis ikan nila.

Untuk pencapaian hal tersebut, maka aktifitas yang disajikan dalam penyuluhan dan pelatihan ini antara lain:

a) Mengurangi biaya produksi terutama pakan ikan

b) Transfer teknologi tepat guna bidang pengolahan hasil perikanan kepada petani ikan sebagai pelaku usaha pengolahan ikan

Melatih analisis prospek usaha pengolahan sehingga menghasilkan rencana pengembangan usaha kedepan secara berkelanjutan.

Bahan untuk membuat pelet seperti di atas menghasilkan pelet yang sudah jadi sebnayak $100 \mathrm{~kg}$.

Dengan demikian biaya produksi pelet perkilo Rp 4.000.

Harga pelet komersil Rp 8.620, jika produksi sendiri Rp 4000. Dengan demikian selisih antra pelet komersil dengan pelet buatan sendiri Rp 4.620 .

\section{Perubahan Strategi Pemasaran}

Selama ini kekurangan yang dimiliki oleh mitra selain keterbatasan jumlah produk adalah minimnya promosi produk. Ikan nila hanya dijual ke pengepul dan pada saat ada pasar mingguan 
dengan harga jual Rp. 23.000,- per kg. Hal ini menyebabkan tidak banyak masyarakat yang mengetahui keberadaan industri ikan nila mitra. Strategi pemasaran yang akan dilakukan dari sisi produk adalah dengan menciptakan produk yang disukai konsumen dan dan menjaga konsistensinya. Dari sisi perluasan pasar dilakukan dengan memperluas daerah penjualan dan lokasi penjualan yang strategis seperti di warung-warung milik masyarakat, pasar mingguan di desa lain dan beberapa mini market.

Tabel 1. Bahan dan Harga Membuat Pelet

\begin{tabular}{lccr}
\hline \multicolumn{1}{c}{ Bahan } & Harga $(\mathbf{R p}) / \mathbf{K g}$ & Jumlah & Total Harga (Rp) \\
\hline Dedak & 3.500 & $60 \mathrm{~kg}$ & 210.000 \\
Ikan Asin & 4.000 & $30 \mathrm{~kg}$ & 120.000 \\
Bukil & 1.500 & $10 \mathrm{~kg}$ & 15.000 \\
Sayur & 1.000 & $5 \mathrm{~kg}$ & 5.000 \\
BBM & & & 50.000 \\
Operasional & & & \\
Jumlah & & & 400.000 \\
\hline
\end{tabular}

\section{KESIMPULAN}

Berdasarkan uraian hasil dan pembahasan di atas dapat disimpulkan bahwa; antusias yang sangat baik yang ditunjukkan dari petani ikan nila terhadap kegiatan PKM ini, dengan pemberian mesin pelet bisa meningkatkan pendapatan petani nila. Perbedaan harga felet komersil dan pelet yang diproduksi dengan mesin pelet adalah $\mathrm{Rp}$ $4.620,-$, dan strategi pemasaran dilakukan dengan pembuatan brosur, pengemasan olahan ikan yang menarik, serta pemasaran olahan tersebut diswalayan dan di toko-toko.

\section{UCAPAN TERIMAKASIH}

Kegiatan ini dapat terlaksana dengan lancar atas partisipasi dari berbagai pihak. Untuk itu tim pengabdian mengucapkan terima kasih kepada: Ditjen Dikti melalui Kopertis wilayah $\mathrm{X}$ yang telah memberikan dana. Lembaga Penelitian dan Pengabdian pada Masyarakat (LPPM) Universitas Pahlawan Tuanku Tambusai yang telah memfasilitasi kegiatan, dan semua pihak yang ikut membantu kelancaran kegiatan pengabdian masyarakat ini

\section{DAFTAR PUSTAKA}

Andriani, T. (2014). Pelatihan Pengolahan Ikan Patin Menjadi Makanan Variatif dan Produktif di Desa Sawah Kecamatan Kampar Utara Kabupaten Kampar. Menara Riau, 13(1), 72-87.

Dinas Perikanan Kabupaten Kampar. (2013). Salai Ikan Nila jadi Ikon Riau.

Dinas Perikanan Provinsi Riau. (2015). Budidaya Ikan di Kampar Terbaik Nasional.

Leksono, K. Y., Setiyo, Y., \& Tika, I. W. (2014). Modifikasi Mesin Pencetak Pakan Budidaya Lele Berbentuk Pellet dengan Kebutuhan Daya Rendah. Jurnal Beta (Biosistem Dan Teknik Pertanian), 2(1), $1-9$

Purnomo, P., \& Suhanda, J. (2014). Diversifikasi Olahan Berbasis Ikan Patin Di Desa Jingah Habang Hilir Kecamatan Karang Intan Kabupaten Banjar Kalimantan Selatan Diversification Processed Based Catfish in the Village of Jingah Habang Hilir Sub-District Karang Intan District Banjar South K. Fish Scientiae, 4(8), 8080. 